\title{
Low-field nuclear magnetic resonance relaxation study of thermal effects on milk proteins
}

\author{
BY PIERRE LAMBELET, RAFAEL BERROCAL \\ AND FRANCINE RENEVEY \\ NESTEC Ltd, Nestlé Research Centre, Vers-chez-les-Blanc, CH-1000 Lausanne 26. \\ Suisse
}

(Received 30 January 1992 and accepted for publication 17 April 1992)

\begin{abstract}
Summary. A recently described nuclear magnetic resonance (NMR) method was evaluated for its usefulness in studying thermal effects on milk proteins. The increase in water proton $\mathrm{T}_{2}$ relaxation rate observed during thermal treatment of aqueous whey protein solutions above the denaturing onset temperature paralleled results obtained with the standard Rowland (1938) method. The influence of milk constituents on NMR characteristics was analysed. The NMR response increased with the ionic strength and the addition of caseinate or casein micelles. The relevance of the $\mathrm{T}_{2}$ relaxation probe for studying thermal modifications of milk proteins is discussed. It is proposed to apply the NMR method for determining either reversible or irreversible thermal denaturation of whey proteins in model systems.
\end{abstract}

The functional properties of a food product, governed by the state of the proteins, are a key factor in food technology. Low resolution nuclear magnetic resonance (NMR) spectroscopy can be an alternative to current methods for studying protein thermal denaturation (Pumpernik et al. 1975; Oakes, 1976a, b; Blicharska \& Rydzy, 1979; Rydzy \& Skrzynski, 1980; Goldsmith \& Toledo, 1985). In order to eliminate the effect of temperature on relaxation, we proposed for the study of protein thermal denaturation by NMR spectroscopy a method in which the measurements are always effected at the same temperature (Lambelet et al. 1989). Under these conditions thermal denaturation of diamagnetic whey proteins was expressed by an increase in water proton transverse relaxation rate $\left(1 / \mathrm{T}_{2}\right)$ (Lambelet et al. 1989 ) while a decrease in this value was recorded during thermal denaturation of paramagnetic proteins such as Fe-saturated transferrins (Lambelet et al. 1991).

Thermal denaturation of whey proteins is also governed by 'environmental' factors (Mulvihill \& Donovan, 1987), such as ionic strength (Mulvihill \& Kinsella, 1988), specific ions such as $\mathrm{Ca}^{2+}$ (De Wit, 1981; Mulvihill \& Kinsella, 1988) and casein (Reddy \& Kinsella, 1990). The present paper describes the influence of these factors on the NMR response recorded during the denaturation of whey proteins, and discusses the potential and limitations of the NMR method for investigating thermal effects on proteins in casein, whey protein isolates and model milk samples.

MATERIALS AND METHODS

\section{Materials}

Whey protein isolate (WPI) prepared by hydrophilic ion-exchange chromatography was purchased from Le Sueur Isolates (Le Sueur, MN 96058, USA). The 
product had a protein content of $90 \cdot 4 \%$. Freeze-dried $\kappa$-casein was purchased from Sigma (CH-9470 Buchs).

\section{Dialysed skim milk}

Raw cows' milk was defatted by centrifugation at $4800 \mathrm{~g}$ and $30^{\circ} \mathrm{C}$ for $30 \mathrm{~min}$ and dialysed at $4{ }^{\circ} \mathrm{C}$ using 6000-8000 Da membranes against 12 vol. distilled water for $\sim 2.5 \mathrm{~h}$. This last operation was repeated six times. The freeze-dried powder had a protein content of $69.2 \%$ of which $59.3 \%$ was casein (Kjeldahl $\mathrm{N} \times 6.38$ of the fraction precipitated at $\mathrm{pH} \mathbf{4 \cdot 6}$ with an acetate buffer).

\section{Sodium caseinate}

Sodium caseinate was prepared from raw skim milk by precipitation at $\mathrm{pH} 4 \cdot 6$ with $\mathrm{M}-\mathrm{HCl}$ followed by centrifugation at $4800 \mathrm{~g}$, dissolution of the deposit in water at $\mathrm{pH} 7.5$ with $\mathrm{m}-\mathrm{NaOH}$, reprecipitation at $\mathrm{pH} 4 \cdot 6$, centrifugation at $4800 \mathrm{~g}$, washing of the deposit with demineralized water and resolubilization at $\mathrm{pH} 7.5$ with $\mathrm{M}-\mathrm{NaOH}$. The solution was spray dried and the powder obtained had a protein content of $81 \cdot 6 \%$.

\section{Casein micelles}

Casein micelles were isolated from raw skim milk by ultracentrifugation at $100000 \mathrm{~g}$ and $10-30^{\circ} \mathrm{C}$ for $90 \mathrm{~min}$. The micelles obtained were collected and freeze dried. They had a protein content of $85.5 \%$.

\section{Sample preparation}

Protein solutions were prepared by mixing at room temperature the proteins (whey proteins alone or in admixture with casein micelles or sodium caseinate) with either distilled water or with aqueous solution of $\mathrm{KCl}$ or $\mathrm{CaCl}_{2}$. After their $\mathrm{pH}$ had been adjusted to 7 with $0 \cdot 1 \mathrm{M}-\mathrm{NaOH}$, the solutions were degassed under vacuum. Denaturation was achieved (1) by heating the sample for $30 \mathrm{~min}$ successively at increasing temperatures between $20^{\circ} \mathrm{C}$ and $110^{\circ} \mathrm{C}\left(10^{\circ} \mathrm{C}\right.$ interval) or $(2)$ by heating the sample at a constant temperature $>50^{\circ} \mathrm{C}$ directly in the $\mathrm{NMR}$ cavity. In the first case the NMR measurements were carried out following each thermal treatment, on samples kept at $20^{\circ} \mathrm{C}$ for $30 \mathrm{~min}$. In the second case $\mathrm{NMR}$ results were continuously recorded with time.

\section{Determination of protein content and protein denaturation (Rowland, 1938)}

Total $\mathrm{N}$ was determined according to the method of Association of Official Analytical Chemists (1980). The protein content was calculated by subtracting the non-protein N (NPN; measured after precipitation in the presence of $12 \%$ trichloroacetic acid) from the total $\mathrm{N}$. Whey protein $\mathrm{N}$ (WPN) was calculated by

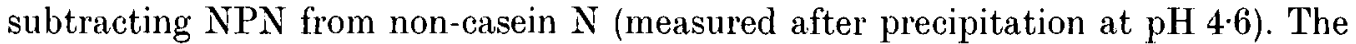
percent denaturation was calculated by comparing the WPN in heat-treated and in raw samples.

$$
\text { Denaturation, } \%=\frac{W P N_{\text {raw }}-W P N_{\text {treated }}}{W P N_{\text {raw }}} \times 100
$$

\section{NMR measurements}

NMR measurements were run on a Minispec PC20 (Bruker Physik AG, 7501 Karlsruhe, Germany) at a resonance frequency of $20 \mathrm{MHz}$. The spectrometer was coupled to an HP 950 computer allowing automatic data acquisition. $\mathrm{T}_{2}$ relaxation 




Fig. 1. Water proton $\mathrm{T}_{2}$ relaxation rates in whey protein isolate (WPI) solutions heated for $30 \mathrm{~min}$ successively at increasing temperatures between 20 and $100^{\circ} \mathrm{C}\left(10^{\circ} \mathrm{C}\right.$ interval $): 0,3 \% \mathrm{WPI}$ solution; ,$+ 10 \%$ WPI solution.

times were determined from the spin echoes decay curve (169 echoes) observed with a Carr-Pursell-Meiboom-Gill pulse sequence. $T_{2}$ relaxation times were calculated by performing nonlinear regression of exponential to the decay curves.

\section{RESULTS}

As the $T_{2}$ relaxation probe has been shown to be more sensitive than $T_{1}$ for measuring denaturation of diamagnetic proteins by heat (Oakes, 1976a, $b$; Lambelet et al. 1989), $\mathrm{T}_{2}$ was exclusively used in the present study. Whatever the thermal treatment applied, water proton $\mathbf{T}_{2}$ relaxation in all milk models investigated could be analysed in terms of a single exponential.

\section{Whey proteins aqueous solutions}

When an aqueous solution of WPI ( 3 or $10 \% \mathrm{w} / \mathrm{v})$ was heated for $30 \mathrm{~min}$ at temperatures ranging from 20 to $100{ }^{\circ} \mathrm{C}$ and then cooled to $20^{\circ} \mathrm{C}$, a rise in water proton $T_{2}$ relaxation rate was recorded after thermal treatment between 60 and $80^{\circ} \mathrm{C}$ (Fig. 1); the variation in $\mathrm{T}_{2}$ relaxation rate increased with the protein concentration. In contrast, no modification of this rate was observed outside this temperature range.

Thermal denaturation measured by the standard Rowland (1938) method while heating a $10 \%(\mathrm{w} / \mathrm{v})$ WPI aqueous solution at $60,67,72$ or $75{ }^{\circ} \mathrm{C}$ is displayed in Fig. 2 . Whatever the temperature of the thermal treatment between 67 and $75{ }^{\circ} \mathrm{C}, \sim 98 \%$ denaturation was observed after $10 \mathrm{~h}$ heating.

The denaturation rate increased with temperature in the range $60-75{ }^{\circ} \mathrm{C}$. The $\mathrm{T}_{2}$ relaxation rates jointly measured during heating these whey protein solutions showed the same tendency (Fig. 3). But for small differences due to the dependence of relaxation rate on the temperature, the relaxation rates recorded after $10 \mathrm{~h}$ were identical for any heating temperature between 67 and $75^{\circ} \mathrm{C}$. Moreover, even at $60^{\circ} \mathrm{C}$ the NMR signal reached the same level as those measured at higher temperatures, but this was after $\sim 25 \mathrm{~h}$ heating (results not shown). The variation of the NMR response with time was slow at $60^{\circ} \mathrm{C}$, intermediate at $67{ }^{\circ} \mathrm{C}$ and rapid at 72 or $75^{\circ} \mathrm{C}$. 


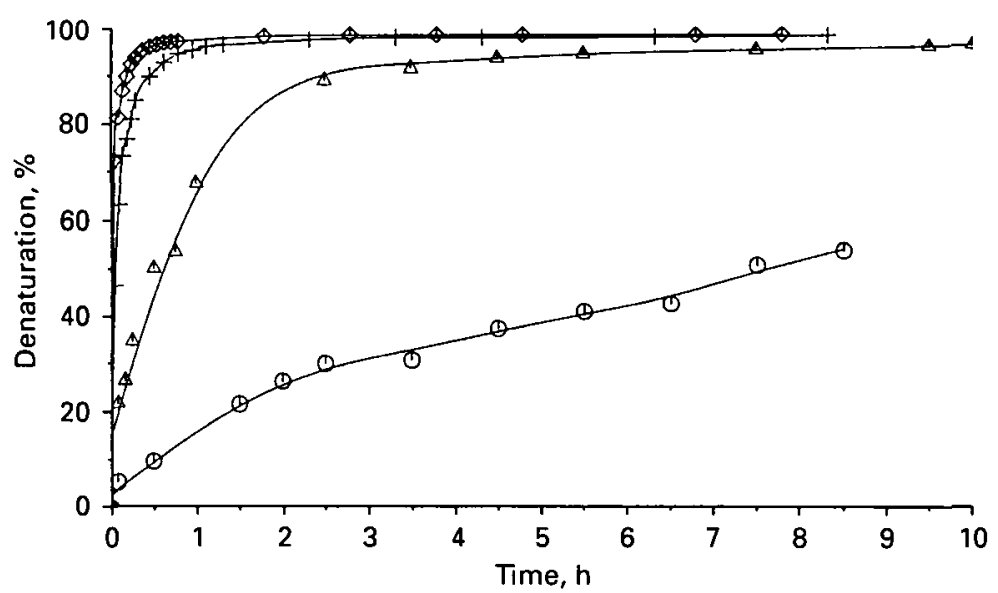

Fig. 2. Time course of denaturation as determined by the method of Rowland (1938) in $10 \%$ $(\mathrm{w} / \mathrm{v})$ whey protein isolate solutions heated at $O, 60^{\circ} \mathrm{C} ; \triangle, 67^{\circ} \mathrm{C} ;+, 72{ }^{\circ} \mathrm{C} ; \diamond, 75^{\circ} \mathrm{C}$.



Fig. 3. Time course of water proton $\mathrm{T}_{2}$ relaxation rates in $10 \%(\mathrm{w} / \mathrm{v})$ whey protein isolate solutions heated at $\square, 50^{\circ} \mathrm{C} ; 0,60^{\circ} \mathrm{C} ; \triangle, 67^{\circ} \mathrm{C} ;+, 72^{\circ} \mathrm{C} ; \diamond, 75^{\circ} \mathrm{C}$.

At $50{ }^{\circ} \mathrm{C}$, i.e. below the onset denaturing temperature, no change in the NMR signal was observed.

Whey proteins in $\mathrm{KCl}$ or $\mathrm{CaCl}_{2}$ solutions

Successive heatings at temperatures between 20 and $100^{\circ} \mathrm{C}$ of $10 \%$ (w/v) WPI in $10 \mathrm{~mm}-\mathrm{KCl}, 100 \mathrm{~mm}-\mathrm{KCl}$ or $10 \mathrm{~mm}^{-\mathrm{CaCl}_{2}}$ solutions gave $\mathrm{NMR}$ responses (Fig. 4) similar to those recorded in pure aqueous solutions (Fig. 1). An increase in water proton $\mathrm{T}_{2}$ relaxation rate was thus recorded after thermal treatment between 60 and $80^{\circ} \mathrm{C}$. The NMR response, however, was slightly enhanced in the presence of the salts.

The effects of these salts on isothermal denaturation $\left(67^{\circ} \mathrm{C}\right)$ determined by the Rowland (1938) method are summarized in Fig. 5. The same denaturation level $(\sim 98 \%)$ was found after $10 \mathrm{~h}$ heating whether or not the solution contained a salt. Whilst a tiny decrease of the initial denaturation rate was observed with $100 \mathrm{~mm}$ $\mathrm{KCl}$, a small increase in this rate was recorded in the presence of $10 \mathrm{~mm}-\mathrm{KCl}$ or $33 \mathrm{~mm}-\mathrm{CaCl}_{2}$. 


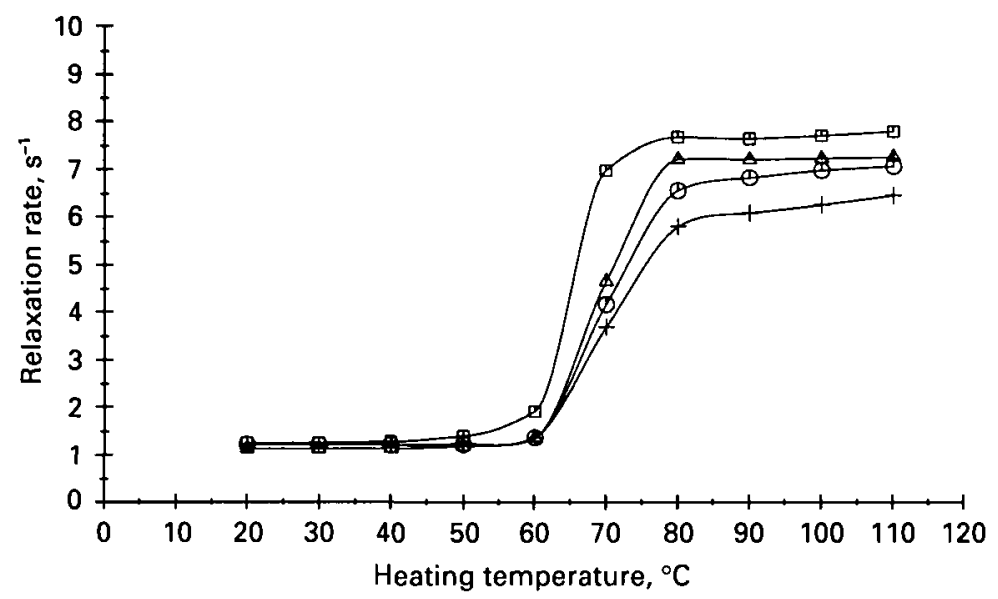

Fig. 4. Water proton $\mathrm{T}$, relaxation rates in $10 \%(\mathrm{w} / \mathrm{v})$ whey protein isolate solutions of different ionic strengths heated for $30 \mathrm{~min}$ successively at increasing temperatures between 20 and $110^{\circ} \mathrm{C}\left(10^{\circ} \mathrm{C}\right.$ interval): + , aqueous solution; $0,10 \mathrm{~mm}-\mathrm{KCl} ; \triangle, 100 \mathrm{~mm}-\mathrm{KCl} ; \square, 33 \mathrm{~mm}-\mathrm{CaCl}_{2}$.

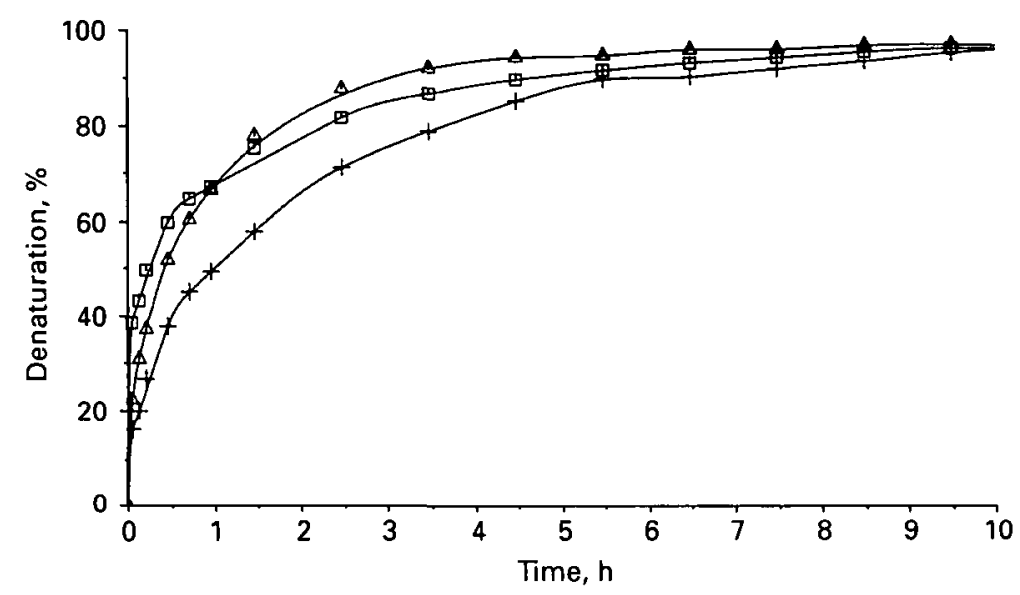

Fig. 5. Time course denaturation (Rowland, 1938) in $10 \%(\mathrm{w} / \mathrm{v})$ whey protein isolate solutions of different ionic strengths heated at $67^{\circ} \mathrm{C}: \triangle .10 \mathrm{mM}-\mathrm{KCl} ;+, 100 \mathrm{~mm}-\mathrm{KCl} ; \square, 33-\mathrm{mm} \mathrm{CaCl}_{2}$.

These salts, however, more drastically modified the NMR response recorded during isothermic heating (Fig. 6). The initial increase in the NMR signal and the level of this signal measured after $10 \mathrm{~h}$ heating at $67^{\circ} \mathrm{C}$ were higher in $10 \mathrm{~mm}-\mathrm{KCl}$ than in pure aqueous solution. These two values were still higher when the solution contained $100 \mathrm{~mm}-\mathrm{KCl}$. In the presence of $33 \mathrm{~mm}-\mathrm{CaCl}_{2}$ the initial slope of the NMR signal was the largest, although the final level reached by this signal after $10 \mathrm{~h}$ heating was similar to that measured in $100 \mathrm{~mm}-\mathrm{KCl}$ solutions (Fig. 6). It is worth noting on the other hand that heating WPI in $10 \mathrm{~mm}-\mathrm{KCl}$ at $67^{\circ} \mathrm{C}$ did not induce gelation while a gel was formed in $100 \mathrm{~mm}-\mathrm{KCl}$ or $33 \mathrm{~mm}^{-\mathrm{CaCl}_{2}}$.

\section{Mixtures of whey proteins and casein in water solutions}

$\mathrm{T}_{2}$ water proton relaxation rate in $12 \%(\mathrm{w} / \mathrm{v})$ sodium caseinate water solution remained constant at $2 \cdot 2 \mathrm{~s}^{-1}$ during heating for $30 \mathrm{~min}$ at $90^{\circ} \mathrm{C}$. The $\mathrm{T}_{2}$ relaxation rates in $3 \%(\mathrm{w} / \mathrm{v})$ WPI solutions containing various amounts of sodium caseinate 


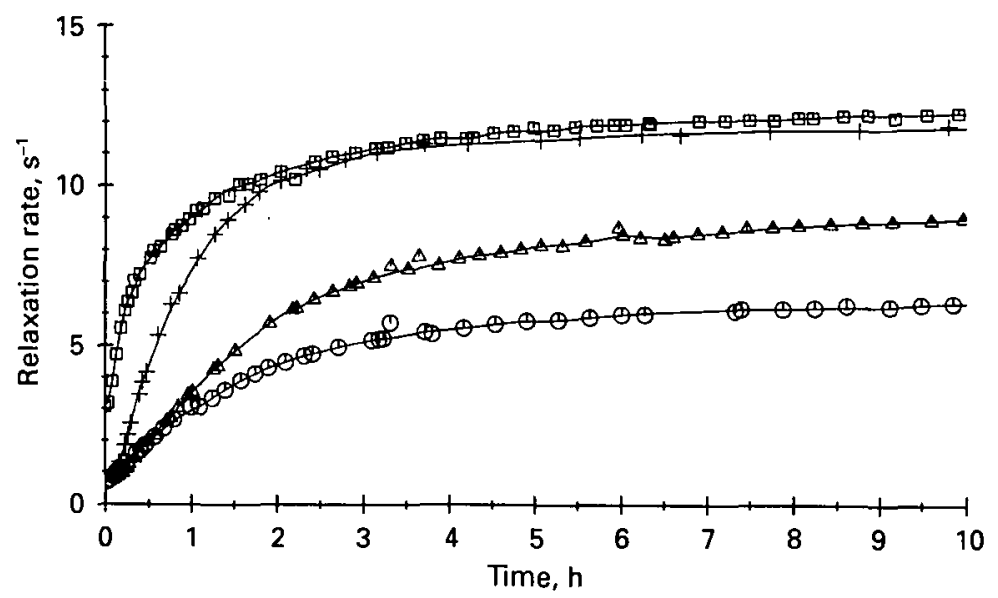

Fig. 6. Time course of water proton $\mathrm{T}_{2}$ relaxation rates in $10 \%(\mathrm{w} / \mathrm{v})$ whey protein isolate solutions of different ionic strengths heated at $67^{\circ} \mathrm{C}: O$, aqueous solution; $\triangle, 10 \mathrm{~mm}-\mathrm{KCl} ;+, 100 \mathrm{mM}-\mathrm{KCl} ; \square$, $33 \mathrm{mM}-\mathrm{CaCl}_{2}$.

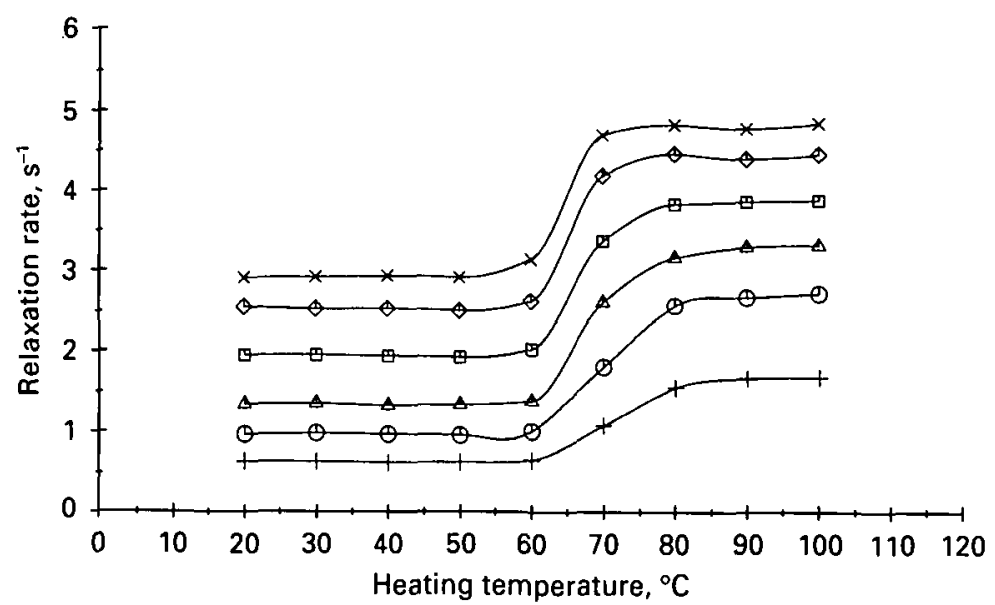

Fig. 7. Water proton $T_{2}$ relaxation rates in $10 \%(w / v)$ whey protein isolate solutions with added sodium caseinate heated for $30 \mathrm{~min}$ successively at increasing temperatures between 20 and $100^{\circ} \mathrm{C}$ $\left(10{ }^{\circ} \mathrm{C}\right.$ interval). Addition of caseinate $(w / v):+$, no addition; $O, 3 \% ; \triangle, 5 \% ; \square, 8 \% ; \diamond, 10 \%, x$, $12 \%$.

$(0-12 \% \mathrm{w} / \mathrm{v})$ increased linearly with the content of caseinate. For all these solutions, however, an increase in $\mathrm{T}_{2}$ water proton relaxation rate was observed following heating in the temperature range $60-80^{\circ} \mathrm{C}$ (Fig. 7). This NMR response to WPI thermal denaturation steadily increased with sodium caseinate concentration. Heating a $3 \%(\mathrm{w} / \mathrm{v})$ WPI solution containing $1.44 \%(\mathrm{w} / \mathrm{v}) \kappa$-casein for $30 \mathrm{~min}$ at $90{ }^{\circ} \mathrm{C}$ led to an increase in $\mathrm{T}_{2}$ relaxation rate of $1.5 \mathrm{~s}^{-1}$, i.e. a smaller NMR response than that recorded in the presence of $12 \%(\mathrm{w} / \mathrm{v})$ sodium caseinate $\left(1.7 \mathrm{~s}^{-1}\right)$.

Replacing sodium caseinate by casein micelles led to the recording of similar but higher NMR responses: no modification of $\mathrm{T}_{2}$ relaxation rate in $12 \%$ casein micelle aqueous solution $\left(14 \mathrm{~s}^{-1}\right)$ was recorded during heating to $90{ }^{\circ} \mathrm{C}$ and a rise in this NMR value was observed while heating mixtures of $3 \%$ WPI with either 6 or $12 \%$ casein micelles between 60 and $80^{\circ} \mathrm{C}$ (Fig. 8). 


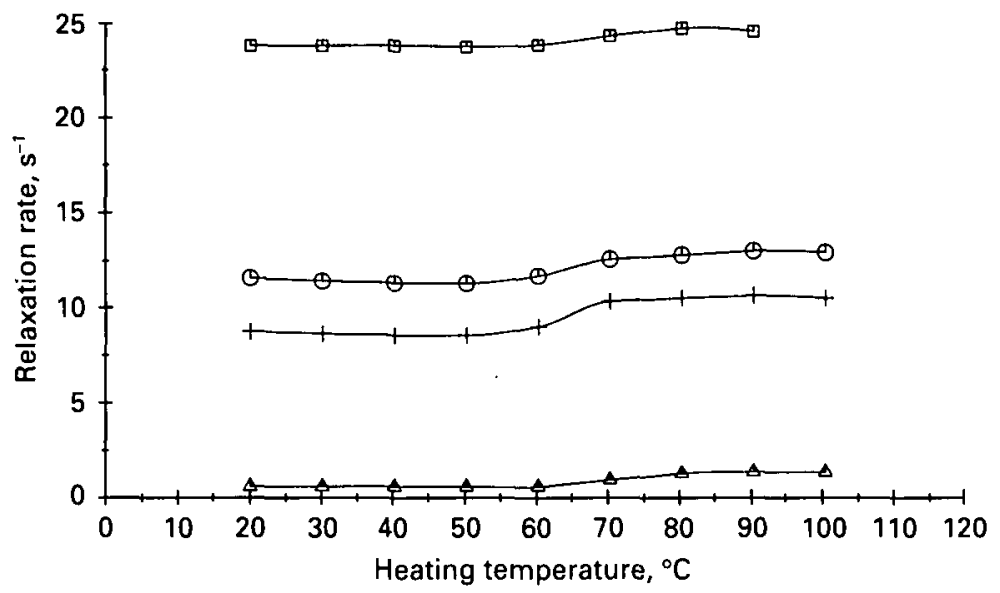

Fig. 8. Water proton $\mathrm{T}_{2}$ relaxation rates in milk models heated for $30 \mathrm{~min}$ successively at increasing temperatures between 20 and $100^{\circ} \mathrm{C}\left(10^{\circ} \mathrm{C}\right.$ interval). $\triangle, 3 \%$ whey protein isolate (WPI);,$+ 3 \%$ WPI $+6 \%$ casein micelles; $0,3 \%$ WPI $+12 \%$ casein micelles; $\square$, dialysed skim milk with $26 \%$ dry matter.

\section{Dialysed skim milk}

Heating dialysed skim milk ( $26 \%$ dry matter) led to constant $\mathrm{T}_{2}$ relaxation rates up to $60^{\circ} \mathrm{C}$, increasing rates to $80^{\circ} \mathrm{C}$ and then an almost constant rate up to $90{ }^{\circ} \mathrm{C}$ (Fig. 8).

\section{DISCUSSION}

NMR data measured in dilute whey protein-water systems can be interpreted in terms of a fast exchange between bound and free water populations (Derbyshire, 1982 ; Padua et al. 1991). The finding that the water $\mathrm{T}_{2}$ proton relaxation was purely exponential in all whey protein-water systems investigated in the present study is consistent with such a fast exchange. It is worth noting that protein-water systems are also characterized by a chemical exchange between labile protein protons and water protons. Such chemical exchange has been postulated in whey protein-water systems (Oakes, 1976a; Lambelet et al. 1988; Hills et al. 1990).

The water proton relaxation rates in aqueous solutions of whey proteins were found to be linearly related to the protein concentrations in the range $0-15 \%$ (Lambelet et al. 1988, 1989). This indicates that the protein activity is small in this concentration range, and does not contribute to the proton relaxation rate (Kumosinski \& Pessen, 1982; Myers-Betts \& Baianu, 1990).

It was shown that the protein proton transverse relaxation rate becomes much higher during the thermal denaturation of bovine serum albumin (Oakes, 1976a). This indicates that the protein chain becomes much more rigid upon denaturation. The increase in the $\mathrm{T}_{2}$ relaxation rate of water protons during thermal denaturation of bovine serum albumin was thus explained in terms of enhancement in the bound water proton transverse relaxation rate associated with a decrease in protein chain mobility (Oakes, 1976a). The NMR response observed during heating whey protein solutions (Fig. 1) can be understood in a similar way, i.e. can be ascribed to protein unfolding. As no gel was formed under the present conditions the NMR response was not related to gelification.

This NMR response can therefore be used for determining the denaturation following thermal treatment of whey proteins in aqueous solution. A good correlation 
was indeed obtained between the NMR and the standard Rowland (1938) methods for measuring whey protein denaturation after thermal treatment (Lambelet $e t$ al. 1989). The present results (Fig. 3) show that the NMR method is also appropriate for determining whey protein denaturation during isothermal heating.

The influence of salt ( $\mathrm{KCl}$ or $\left.\mathrm{CaCl}_{2}\right)$, added prior to heating, on the $\mathrm{NMR}$ response recorded during whey protein denaturation (Fig. 6) was twofold. First, an increase occurred in the slope of the NMR signal recorded at the beginning of the denaturation process; this slope depended on the nature and on the concentration of the salt, the largest slope being obtained with $33 \mathrm{~mm}-\mathrm{CaCl}_{2}$. These effects of $\mathrm{KCl}$ and $\mathrm{CaCl}_{2}$ salts on whey thermal denaturation were consistent with those measured with the Rowland (1938) method (Fig. 5). Second, there was an increase in the plateau reached after complete denaturation. Its level was proportional to the ionic strength of the solution as shown by the similarity of the results obtained after $10 \mathrm{~h}$ heating in the presence of $33 \mathrm{~mm}-\mathrm{CaCl}_{2}$ and $100 \mathrm{~mm}-\mathrm{KCl}$. In this case the $\mathrm{NMR}$ response cannot be related to denaturation as measured by the Rowland (1938) method. Indeed, with the Rowland (1938) method a degree of denaturation of $\sim 100 \%$ is always recorded after $10 \mathrm{~h}$ heating. Aggregation of whey proteins during heat treatment is known to be affected primarily by their ionic environment (De Rham \& Chanton, 1984; Donovan \& Mulvihill, 1987). Although not influenced by gelification, nor by polymerization through the establishment of intermolecular disulphide bonds (Lambelet et al. 1989), the $\mathbf{T}_{2}$ probe is probably sensitive not only to protein unfolding but also to some protein association. This might arise from the addition of salts inducing a decrease in the repulsive forces between proteins: the protein-protein association is improved (Mulvihill et al. 1990; Mulvihill \& Kinsella, 1988), making the water bound to the protein less mobile.

Casein also influences the NMR probe. The $\mathrm{T}_{2}$ water proton relaxation in solutions containing $3 \%$ whey proteins and $12 \%$ sodium caseinate was slow (slightly more rapid than in $3 \%$ whey proteins solution) while it was much faster in the presence of $3 \%$ whey proteins and $12 \%$ casein micelles. This observation, previously reported (Kumosinski et al. 1987; Farrell et al. 1989), can be explained by the difference in structure between casein micelles (spherical particles with high amounts of interstitial water) and caseinate. At the same protein concentration ( $3 \%$ whey protein and $12 \%$ casein micelles) $T_{2}$ relaxation was even more rapid in dialysed skim milk, probably owing to the other constituents present in the milk. Although the NMR signal related to protein denaturation in dialysed skim milk was similar to that recorded with the corresponding amount of whey proteins, this signal was increased in the presence of sodium caseinate (Fig. 7) or casein micelles (Fig. 8). This enhancement might be associated with the formation of a complex on heating $\beta$ lactoglobulin with $\kappa$-casein (Reddy \& Kinsella, 1990). However, this complex cannot account for the entire increase observed. Indeed, $\kappa$-casein added to whey proteins in an amount equal to that present in sodium caseinate produced a smaller effect than did sodium caseinate.

It appears that, like thermal denaturation or aggregation, the NMR response is influenced by environmental factors (ionic strength, casein). The NMR method cannot therefore be universally applied. Like the standard Rowland (1938) solubility assay (De Rham \& Chanton, 1984), the NMR method is valid under restricted conditions. Nevertheless, it is a powerful tool for studying thermal denaturation of pure whey proteins, whey protein concentrates or isolates. Using the NMR method, denaturation can be measured either discontinuously by recording values at $20^{\circ} \mathrm{C}$ after the thermal treatments or by continuously sampling information above the 
denaturing onset temperature. As a matter of fact, under these conditions the effect of temperature on the relaxation rates is cancelled. Furthermore, as the relaxation curves can be recorded semi-automatically during isothermal treatment, the NMR method is very convenient for following denaturation at a constant temperature.

No attempt was made to calculate kinetic information from the whey proteins denaturation curves obtained with the NMR method (Fig. 3) since the relative denaturation rates of the individual proteins differ (Donovan \& Mulvihill, 1987). The NMR method is, however, appropriate for kinetic determinations. On the other hand, while irreversible denaturation is observed when the measures are made at $20{ }^{\circ} \mathrm{C}$, reversible effects can be detected when the measures are made above the denaturing onset temperature. This could be useful for studying heat-induced denaturation of e.g. $\beta$-lactoglobulin and $\alpha$-lactalbumin.

The authors thank Ms C.-E. Buxcel for skilful technical assistance.

\section{REFERENCES}

Assoclation of Official Analytical Chemists 1980 Official Methods of Analysis of the AOAC, 13th edn, Methods 16.047, 16.048 and 47.021 (Ed. W. Horwitz). Washington, DC: AOAC

Blicharska, B. \& RYDzr, M. 1979 Investigation of protein denaturation by nuclear magnetic relaxation method. Acla Physica Polonica A56 439-443

Derbyshire, W. 1982 The dynamics of water in heterogeneous systems with emphasis on subzero temperatures. In Water: a Comprehensive Treatise, vol. 7, pp 339-430 (Ed. F. Franks). New York: Plenum Press

De Rham, O. \& Chanton, S. 1984 Role of ionic environment in insolubilization of whey protein during heat treatment of whey products. Journal of Dairy Science $67939-949$

DE WLT, J. N. 1981 Structure and functional behaviour of whey proteins. Netherlands Milk and Dairy Journal $3547-64$

Donovas, M. \& MulviHILL, D. M. 1987 Thermal denaturation and aggregation of whey proteins. Irish Journal of Food Science and Technology 11 87-100

Farrelu, H, M., Pessen, H. \& Kumosinski, T. F. 1989 Water interactions with bovine caseins by hydrogen2 nuclear magnetic resonance relaxation studies: structural implications. Journal of Dairy Science 72 562-574

Goldsmith, S. M. \& Toledo, R. T. 1985 Studies on egg albumen gelation using nuclear magnetic resonance. Journal of Food Science $5059-62$

Hills, B. P., Takacs, S.F. \& BeLton P.S. 1990 A new interpretation of proton NMR relaxation time measurements of water in food. Food Chemistry $3795-111$

Kumosinski, T. F. \& Pessen, H. 1982 A deuteron and proton magnetic resonance relaxation study of $\beta$-lactoglobulin A association: some approaches to the Scatchard hydration of globular proteins. Archives of Biochemistry and Biophysics 218 286-302

Kumosinski, T. F., Pessen, H., Prestrelsei, S. J. \& Farreld, H. M. 1987 Water interactions with varying molecular states of bovine casein: ${ }^{2} \mathrm{H}$ NMR relaxation studies. Archives of Biochemistry and Biophysics 257 $259-268$

Lambelet, P., Berrocal, R., Desarzens, C., Froehlicher, I. \& Ducret, F. 1988 Pulsed low-resolution NMR investigations of protein sols and gels. Journal of Food Science 53 943-946, 964

Lambelet, P., Berrocal, R. \& Ducret, F. 1989 Low resolution NMR spectroscopy : a tool to study protein denaturation. I. Application to diamagnetic whey proteins. Journal of Dairy Research 56 211-222

Lambelet, P., Ducret, F., Leuba, J. L. \& Geoffroy, M. 1991 Low-field NMR relaxation study of the thermal denaturation of transferrins. Journal of Agricultural and Food Chemistry 39 287-292

Mulvihll, D. M. \& Donovan, M. 1987 Whey proteins and their thermal denaturation - a review. Irish Journal of Food Science and Technology $1143-75$

Mulvihilt, D. M. \& Kinselda, J. E. 1988 Gelation of $\beta$-lactoglobulin : effects of sodium chloride and calcium chloride on the rheological and structural properties of gels. Journal of Food Science 53 231-236

Mulvihill, D. M., Rector, D. \& Kinselda, J. E. 1990 Effects of structuring and destructuring anionic ions on the rheological properties of thermally-induced $\beta$-lactoglobulin gels. Food Hydrocolloids $4267-276$

Myers-Betts, P. A. \& Baland, I. C. 1990 Approaches to protein hydration and water activity in food proteins by nuclear magnetic relaxation and vapor pressure equilibration techniques. Journal of Agricultural and Food Chemistry 38 1171-1177

OAKES, J. 1976 a Protein hydration. Nuclear magnetic resonance relaxation studies of the state of water in native bovine serum albumin solutions. Journal of the Chemical Society, Faraday Transactions $172216-227$

OAKES, J. $1976 b$ Thermally denatured proteins. Nuclear magnetic resonance, binding isotherm and chemical modification studies of thermally denatured bovine serum albumin. Journal of the Chemical Society, Faraday Transactions I 72 228-237 
Padva, G. W., Richardson, S. J. \& Steinberg, M. P. 1991 Water associated with whey protein investigated by pulsed NMR. Journal of Food Science 56 1557-1561

Pumpernik, D., Fajt, B., Lapanje, S. \& Ažman, A. 1975 NMR relaxation study of the thermal denaturation of lysozyme. Zeitschrift für Naturforschung 30C 294-295

REDDY, I. M. \& KINSELLA, J. E. 1990 Interaction of $\beta$-lactoglobulin with $\kappa$-casein in micelles as assessed by chymosin hydrolysis : effect of temperature, heating time, $\beta$-lactoglobulin concentration, and $p \mathrm{H}$. Journal of Agricultural and Food Chemistry 38 50-58

Rowland, S. J. 1938 The determination of the nitrogen distribution in milk. Journal of Dairy Research 94246

Ry DzY, M. \& SkRzY NSki, W. 1980 Investigation of $\beta$-galactosidase thermal denaturation by nuclear magnetic relaxation method. Studia Biophysica 78 119-126 